811.163.41'374

821.163.41.09-14:398]:81'373

https://doi.org/10.18485/sj.2020.25.1.18

ИВАНА ЛАЗИЋ-КОЊИК*

Институт за српски језик САНУ, Београд

МАРИЈАН Ј. ЈЕЛИЪ ${ }^{* *}$

Универзитет у Новом Саду

Педагошки факултет у Сомбору
Оригиналан научни рад

Примљен: 15. 10. 2019.

Прихваћен: 15. 01. 2020.

\title{
ЛЕКСИКА СРПСКИХ НАРОДНИХ ПЕСАМА У СРПСКОМ РЈЕЧНИКУ И У РЕЧНИКУ СРПСКОГ ЈЕЗИКА (ЛЕКСИКОГРАФСКИ АСПЕКТ)
}

У раду се, на грађи прве књиге Вукових Српских народних пјесама, посматра лексика лирских српских народних песама у Вуковом Српском рјечнику $(1898(2017))^{1}$ и у једнотомном Речнику српског језика (2011). Корпус за анализу чине именице које почињу словима $a, 6,6,2, \partial, \hbar e, ~ ж, ~ з, ~ u$ (укупно 654). Рад је подељен у два дела. У првом делу се анализира Вуков однос према лирским народним песмама као грађи за Српски рјечник и представљају статистички подаци за заступљеност посматраних именица у Српском рјечнику. У другом делу се наводе статистички подаци за заступљеност посматраних именица у Речнику српског језика и анализира њихов актуелни језички статус. Показује се у којим случајевима постоји, одн. не постоји основа за њихово уношење у једнотомни речник савременог књижевног језика, с обзиром на њихово место и значај у језичком систему. На тај начин се уједно показују континуитет и промене које су забележене у развоју лексике српског језика у предоченом периоду.

Кључне речи: језик српских народних песама, лексика, Српски рјечник, Речник српског језика, српски језик.

\footnotetext{
*ivana.konjik@isj.sanu.ac.rs

${ }^{* *}$ marijan.jelic@pef.uns.ac.rs

${ }^{1}$ Према његовом дигиталном издању, в. нап. 3 .
} 


\section{УВОД}

1.0. У раду се, у дијахроној перспективи, посматра заступљеност лексике српских лирских народних песама у Вуковом Српском рјечнику (даље: СР) (1898 (2017)) $)^{2}$ и у Речнику српског језика (2011) (даље: РСЈ). Рад се састоји из два дела. У првом делу се анализира Вуков однос према српским лирским народним песмама као грађи за СР, који у досадашњим проучавањима Вуковог лексикографског рада није истражен. У другом делу се анализира заступљеност лексике српских лирских народних песама у савременом српском језику (у PCJ), с циљем да се размотри њен синхрони и дијахрони статус, анализира оправданост уношења у једнотомни речник савременог језика и покажу континуитет и промене у развоју лексике српског језика на посматраном корпусу у назначеном периоду (од појаве СР до данас).

1.1. Корпус за анализу чини материјал именица ексцерпиран из Вукових Српских народних пјесама, књига прва $(1841)^{3}$, у којој су објављене лирске

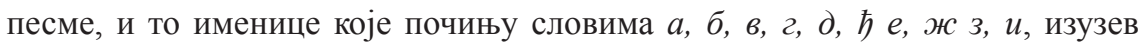
ономастике ${ }^{4}$ (укупно 657 именица). ${ }^{5}$ Речи су ексцерпиране помоћу софтвера AntConc, а сравњивање облика и лематизација су урађени ручно. Екавски, (и)јекавски и икавски облици исте речи посматрани су обједињено, док су све остале варијанте неке речи посматране као самосталне речи.

1.2 Именице смо у анализи (у другом делу рада) посматрали систематизовано према тематској класификацији представљеној у раду Лазић-Коњик $2017,{ }^{6}$ јер се на тај начин, без обзира на историјски период српског језика који је у фокусу, стиче целовитији увид у структуру лексичког система, главне семантичке особине и везе између самих појмова постају очигледне, а самим тим и елементи слике света одражени у њима (в. табелу 1).

${ }^{2}$ Испоређивање је вршено на основу дигиталног издања Вуковог Српског рјечника објављеног на платформи http://raskovnik.org/ 2017. год., које представља дигитализовану верзију његовог трећег (1. државног) издања из 1898. год. О разликама у садржају између првог, другог и трећег издања Српског рјечника в. у предговорима ових издања. Податке о дигиталном издању в. у Литератури.

${ }^{3}$ Користили смо издање Просвете и Нолита из 1987. год. Пун библиографски податак в. у одељку Извори.

${ }^{4}$ Вук је у Српски рјечник мало уносио лична и географска имена. Од личних имена уносио је само српска, како каже у Предговору првом издању Рјечника. Овај слој лексике и иначе се сматра најпроблематичнијим у његовом речнику будући да је лична имена највећим делом ексцерпирао из писаног извора (Рачанског поменика), а да је касније утврђено да се многа од тих имена нису користила у Вуково време (исп. Ивић 1991: 69-78).

${ }^{5}$ Поред именица, ексцерпирали смо и све глаголе који почињу наведеним словима (укупно 427), али због ограниченог обима рада нема довољно места да их анализирамо. Зато ће се на одговарајућем месту у раду навести само основни статистички подаци о заступљености глагола у СР и РСЈ.

${ }^{6}$ За ову прилику класификација је ревидирана и допуњена. 
1.2.1. Све посматране именице се, према наведеној класификацији, могу разврстати у три основна тематска (појмовна, концептуална) поља: „Природа”, „Човек” и „Особине света”, у оквиру којих се на основу различитих лексичкосемантичких односа издвајају тематске групе и подгрупе. ${ }^{7}$ Најбројније су именице у пољу „Човек” (457), затим у пољу „Природа” (160), а најмање бројне су именице у пољу „Особине света” (24). Према тематским групама, најбројније су именице у групи „Називи за људе” (117), следе „Кућа и њени делови” (83), „Биљке” (69), затим „Веровања и религија (обреди, обичаји, сујеверје)” (59), „Животиње” (52), „Тело и делови тела” (44), „Друштвена организација” (36), „Одећа” (32), „Земља” (23), „Лепота” (17), ,Занати и занимања” (16), „Небо” (16), „Храна” (13), „Време” (12), „Глас” (11), „Поседовање и трговина” (9), „Ум” (7), „Димензије и физичке особине” (7), „Уметност” (6), „Моралне вредности” (7), „Мере” (1). Као посебне групе, ван класификације, издвојене су група „Остало” (14), у коју су уврштене именице које се не могу уврстити ни у једну од претходних група и група „Глаголске именице” (7), које су иначе специфичне по својој природи јер имају категоријална обележја именица а семантички и синтаксички су сличне глаголима. ${ }^{8}$

Табела 1. Број именицуа према тематским пољима и групама

\begin{tabular}{|c|c|c|}
\hline Природа (160) & Човек (457) & Особине света (20) \\
\hline Биљке (69) & Тело и делови тела (44) & Време (12) \\
\hline Животиње (52) & Називи за људе (117) & Физичке особине (7) \\
\hline Небо (16) & Кућа и њени делови (83) & Бројеви (3) \\
\hline Земља (23) & Одећа (32) & \\
\hline & Лепота (17) & \\
\hline & Уметност (6) & \\
\hline & Ум (7) & \\
\hline & Глас (11) & \\
\hline & Данати и занимања (16) & \\
\hline & Друшт. организација (36) & \\
\hline
\end{tabular}

${ }^{7}$ О природи језичких и ванјезичких односа на којима се заснивају тематске класификације лексике (асоцијативне, логичке и концептуалне сличности, односи род-врста, део-целина, функција, материјал и начин израде, начин употребе и др.), в. у Лазић-Коњик 2017: 615-616 и тамо наведену литературу.

${ }^{8}$ У групи „Остало” су именице: банда, баштина, божоле, груда, дело, дера, дјевојаство, доход, жеља, заповјед, застава, зламење, изун, илинча, а у групи „Глаголске именице”: гледање, говорење, грљење, долажење, жуђене, дерање и ђевовање. 


\begin{tabular}{|c|c|c|}
\hline & Моралне вредности (7) & \\
\hline & Религија и веровања (59) & \\
\hline & Храна (13) & \\
\hline & Поседовање и трговина (9) & \\
\hline
\end{tabular}

1.3. Тематско представљање именица омогућило је такође да се покаже материјална и духовна култура народа у вези са различитим областима свакодневног живота, односно, лирска језичка слика света, која је део фолклорне и традиционалне српске језичке слике света.

\section{ЛЕКСИКА ЛИРСКИХ НАРОДНИХ ПЕСАМА У СРПСКОМ РЈЕЧНИКУ}

\section{Вуков однос према лирским песмама као грађи за СР}

2.0. Вуков однос према лирским народним песмама као грађи за СР није истражен у литератури. Одреднице у речнику сведоче да је Вук користио лирске песме приликом састављања Рјечника, пошто је неке речи или значења илустровао стиховима из лирских народних песама, нпр. аваница 2, адвокат, алет, ал-ћергелет, амбер, армаган, арфа, ахар, ашик, бадњак 2, банда, банити се, батати, бачити, баштина 2, башчованка, безистен, бељарица и др. ${ }^{9}$ Нема, међутим, прецизних података о томе колико је исцрпно Вук уносио лексику ових песама у свој речник, као што знамо да је исцрпно користио лексику појединих епских народних песама (Томић $1938 .{ }^{10}$ и Младеновић $1964^{11}$ ).

${ }^{9}$ У првом издању Српског рјечника примери из лирских песама су наведени код 34 именице које почињу словима а-и, а у другом издању код 168 именица.

${ }^{10}$ Колико се Вук служио у Српском рјечнику Вишњићевим песмама сазнајемо из рада Б. Томића (1938: 95-99). Томић прецизно наводи податке о броју речи које је Вук узео из „најважнијих и највећих" Вишњићевих епских песама: Почетак буне против дахија, Бој на Чокешини, Бој на Салашу, Кнез Иван Кнежевић, Бој на Мишару, Милош Стоићевић и Мехо Оругиић, Бој на Лозници. На пример, из песме Почетак буне против дахија од 901 речи Вук је унео у Рјечник 845 речи, а од 56 речи које није узео 49 су лична и географска имена, па само 7 речи заправо нема код Вука (нав. дело, стр. 95). Након прецизне анализе Томић закључује да је Вук „изузевши нека лична и географска имена и неке споредне категорије речи, употребио у свом речнику у потпуности Вишњићев песнички језик” (нав. дело, стр. 96).

${ }^{11}$ Ж. Младеновић је осветлио начин на који је Вук ексцерпирао песме: „Вук је из народних песама узео много речи и ради њихова тумачења навео је много стихова, свакако и због тога да би српске народне песме, које су после појаве првих двеју његових збирки стекле славу у целоме свету, учинио што приступачнијим читаоцима, а нарочито странцима, који су се за њих јако интересовали, а који су знали један од два језика (немачки и латински), на које су речи у Рјечнику превођене. Због тога је он систематски тумачио скоро сваку реч на коју би у песмама наишао, па чак и оне речи (на пример султипита у стиху 'Султипите на гужву савите') које 
2.1. За разматрање поменутог односа важан је податак да је део лирских песама Вук записао по сопственом сећању ${ }^{12}$ или сам на терену са уста казивача, због чега њихову изворност одн. народност у погледу језика није доводио у питање, па је очекивано да су лексема из лирских песама заступљене у СР.

\section{Заступљеност именица из лирских народних песама у СР}

3.0. Да бисмо проверили полазну претпоставку, извршили смо поређење материјала именица ексцерпираних из СНП 1 са СР, који се гледано на временској равни настанка речника / записивања песама може сматрати савремеником посматраног корпуса. Формално испоређивање корпуса из наведених извора показало је да је Вук готово све именице са посматраног списка унео у свој речник. Од 657 именица Вук је унео 652. Само пет именица (анума, враголом, жалосница, виноберје и ђулсија) није унео у речник. ${ }^{13}$ Може бити да је кованицу враголом сматрао песничком (појединачном) и необичном творевином. Неке речи Вук је свесно изоставио, поготово у првом издању речника, јер их није знао или чуо у говору свога краја. ${ }^{14}$ Неке речи је такође свесно изостављао јер их је сматрао мање познатим обликом исте речи ${ }^{15}$ (то можда може бити разлог за изостављање речи виноберје и ђулсија, јер је у СР унео речи винобер и ђулс и Ђулса); а неке су му речи једноставно промакле приликом обраде. ${ }^{16}$

3.1. За реч везир Вук је у речнику навео само уобичајено значење титуле потврђено у лирским песмама (које је карактеристично и за епске песме): $V$ треће је, у девојке, / Златно пуце под гръоием, / Волео б'га распиьати, / Него

се можда појављују само у случајевима у којима их је у њима нашао” и даље: „Иим би добио неки рукопис народних песама, он је, пре но што би га преписао и редиговао за штампу, ако га је мислио штампати, црвеном оловком подвлачио речи за које је сматрао да треба да уђу у Рјечник и преписивао их заједно са стиховима у којима их је нашао. Судећи по многобројним сачуваним рукописима његове заоставштине у Архиву Српске академије наука и уметности и у Рукописном одељењу Библиотеке 'Салтиков-Шчедрин' у Лењинграду, он је речи и стихове за Рјечник одабирао веома приљежно и систематски." (Младеновић 1964: 281-283). О томе сведоче и Вукове забелешке у рукописима збирки које је добијао, типа „Повађене су ријечи” (нав. дело, стр. 285).

${ }^{12}$ Вук је, према сопственом сведочењу у предговору Мале простонародне славено-сербске пјеснарице (1814), свих 100 објављених женских песма и осам „мужеских” чуо у свом Тршићу и „без никакова намерења запамтио” (стр. 19).

${ }^{13}$ Подаци за глаголе показују да је од 427 глагола који почињу словима $a-u$, Вук у СР унео 422. Није унео глаголе: благодарити, допратити, запостити, застојати се, затрести се.

${ }^{14} \mathrm{O} \mathrm{CP}$, и то посебно његовом првом издању, као речнику говора једног човека, в. Ивић 1991, 69-70.

${ }^{15}$ Ово је запазио Б. Томић: „Код Вука је врло честа појава, кад има главне форме бројева, придева и активних глагола, да изоставља мање важне врсте исте речи” (Томић 1938: 96).

${ }^{16}$ У литератури је констатовано да је Вук неке речи нехотице испустио приликом припреме речника (в. Ивић 1991: 70-71). Б. Томић с правом констатује да у тако великом послу, који је Вук радио готово сам, „лако измакну из вида не само две, три, него и читаве десетине и стотине речи" (Томић 1938: 96). 
царев везир бити (467), док необичну употребу у лирској песми 533: Везир Зејна по бостану везла није унео у СР, вероватно и сам осећајући да се реч везир не употребљава у говору са значењем 'особа која везе, везиља'.

3.2. Постоје такође примери правописне разлике: у песми Демешкињ $а, \mathrm{y}$ СР демешкињ $а$; у песми загорје, у СР Загорје; у песми влаињ $а$, у СР влаињ $а$ и Влахињ $a$, који показују колебања у погледу још увек неизграђене правописне норме.

3.3. Један број лексема је у песмама употребљен у различитим дијалекатским фонетским варијантама и облицима, а Вук их је у Српски рјечник унео у „правилној” форми у складу са правописно-језичком реформом коју је тада спроводио (колебање у погледу елиминације / прихватања фонеме $x$ у народним речима, јотовање и др.), нпр.: у песми је аримандрит, у СР архимандрит и по Вуку правилније акримандрит, у песми је браин, у СР брајан и брајен, итд. (в. табелу 2). ${ }^{17}$

Табела 2. Варијанте: СНП 1 и Српски рјечник

\begin{tabular}{|c|c|}
\hline у песми & у СР \\
\hline аримандрит & архимандрит ${ }^{19}$ и акримандрит \\
\hline браин & брајан и брајен \\
\hline бува & буа и буха \\
\hline вијојла, вијола, виојла & виојла и вијола \\
\hline дел, дијел & део и дијел 2 ('брдо') \\
\hline дјевојаство & дјевојаштво \\
\hline ђенерал & генерал, џенерал и џенерао \\
\hline ђерђев, ђерђеф & ђерђеф \\
\hline зарукавје & зарукавље \\
\hline имбрик & ибрик \\
\hline
\end{tabular}

3.4. У Српском рјечнику постоје случајеви у којима Вук посебно наводи „варијантни облик” одреднице посведочен (само) у лирској песми (са стихом из те песме као примером), а одредницу упућује на „правилну”, уобичајену

${ }^{17}$ У песми налазимо именицу б'јелило у којој је грешком стављен апостроф, што је вероватно и сам Вук увидео па ју је у СР навео као бјелило, а уз њу и пример из лирске песме, такође без апострофа; тако је наведена и у РСАНУ; и ми је узимамо у облику бјелило.

${ }^{18}$ У Српском рјечнику са глосом: „у књижевника”. 
форму коју дефинише (в. део, араилама, демије, болник). Овај Вуков поступак показује његово непосредно схватање сталних промена у лексичком систему на просторној и временској равни, будући да је неке „варијанте” из песама третирао као лексичке варијанте које имају ограничену употребу по просторној заступљености (демије, у СР са глосом „у Ц. г.”) или временској обележености (део, у СР са квалификатором „ист.”), или су функционално-стилски обележене (арашлама, у СР са квалификатором „ст.”, стајаћа, песничка реч, болник, без квалификатора али са стихом из песме као примером) и издвојио их као засебне одреднице у Рјечнику

3.5. Резултати поређења за посматрани корпус показују да је Вук исцрпно користио лирске народне песме као грађу за свој речник и да је из лирских песама узео безмало све речи а разлика која постоји вероватно је, како је показано, настала свесно, а мање вероватно нехотице, јер је Рјечник из 1852, како се зна, састављало више руку, а ту је био ангажован и Даничић. Зато се с великом сигурношћу може тврдити да су лирске народне песме, као и епске, биле један од главних извора Вуку за састављање СР (тврдња се односи на испоређени материјал, али верујемо да ће анализа целокупног материјала показати исто или веома слично). ${ }^{19}$

\section{ЛЕКСИКА ЛИРСКИХ НАРОДНИХ ПЕСАМА У РЕЧНИКУ СРПСКОГ ЈЕЗИКА}

\section{Заступљеност именица из лирских народних песама у РСJ}

4.0. Чињеница да су практично све речи из посматраног корпуса обрађене у СР омогућила је да се успостави однос са савременим извором - $\mathrm{PCJ}^{20}$, и добију подаци о њиховом синхроном статусу и променама које су се одиграле у дијахроном развоју српског језика у назначеном периоду (готово два века), а исто тако да се покаже лексичко језгро, тј. стабилан део лексичког фонда српског језика који претрајава, без обзира на друштвено-историјски развој и

${ }^{19}$ Наше истраживање потврђује да је Ж. Младеновић имао право када је рекао да је Вук пишући речник настојао да протумачи и примерима разјасни скоро сваку реч у својим рукописима народних песама, те да је песме сакупљао „колико ради њихове лепоте толико и ради лексичког блага које је ставио у темеље Српског рјечника" (Младеновић 1964: 290-291). Вук је, на тај начин, својим систематским и преданим радом саставио не само први и изванредан српски речник, него је истовремено усвојио из европске лексикографије свога времена (његова преписка говори о томе са којим је речницима био упознат током састављања Рјечника) и заједно са Копитарем имплементирао у СР узорну методологију лексикографског и научно-истраживачког рада која се у основном задржала до данашњег времена.

${ }^{20} \mathrm{PCJ}$ је једнотомни речник савременог књижевног језика, па би требало да је у такав тип речника, строго узевши, унета лексика која спада у савремени лексички корпус српског језика (исп. РСЈ 2011: 7, параграф 2 с). 
цивилизацијске промене и онај део лексике који се лако мења (припада периферији лексичког система).

4.1. Истраживање П. Ивића из 1964. године, у којем је Ивић упоредио лексику дневног листа Политика са СР, показује да се Вукова лексика прилично разликовала од лексике српског језика Ивићевог времена (више од 57\% речи из Политике нема у СР, исп. Ивић 1991: 11). Реално је очекивати да је са протоком времена та разлика данас још већа.

4.2. Формално поређење корпуса именица из лирских песама са РСJ показује да је од 657 именице 449 именица регистровано у РСЈ (68\%), а да 208 именица није унето у овај речник $(32 \%) .{ }^{21}$ Које су то именице из лирских народних песама опстале у српском језику, а које су из њега нестале, и који су разлози за то?

\section{Именице регистроване у РСЈ}

5.0. Више од половине посматраних именица из лирских народних песама нашло је своје место у РСЈ (68\%). Било би отуда природно да већина њих припада корпусу савременог језика, а да је мањи број унет из културолошких и просветних разлога (нпр. историзми, неки архаизми, који су део школске лектире и сл.). Иако у бројним случајевима јесте тако (нпр. биље, босиљак, босиье, бриљан, детелина, грах, дуван, зеље, боб, жито, зоб, божур, дафина, зумбул, бор, борика, брекиња, врбича, глог, глогиња, грм, дрво, дрвие, дренак, дрењина, дуд, воће, вишња, вишњица, вишњичица, грожђе, гуња, диња, дуња, зеленика, бокор, грана, граница, гранчица, грозд, зрно, зрнце итд.), међу унетим именицама има и доста турцизама и застарелих лексема које се данас не употребљавају, па се поставља питање разлога и оправданости њиховог уношења у једнотомник са становишта савременог књижевног стандарда. ${ }^{22}$ У даљем излагању размотриће се такви примери с обзиром на концепцијске захтеве једнотомног дескриптивног речника и имајући у виду да се приликом израде дескриптивних речника с једне стране настоји унети што је могуће више речи и што је могуће више значења сваке речи како би се обезбедило њихово разумевање у произвољном контексту, а са друге стране одговарајућа

${ }^{21}$ Подаци за глаголе показују да је од 427 глагола у посматраном корпусу 366 регистровано у РСЈ.

22 Диференцирање застареле од архаичне лексике и одређивање степена архаичности неке речи сложени су лексикографски задаци, који делом укључују и субјективну процену лексикографа, али се без обзира на то могу утврдити критеријуми за њихово решавање (в. Радовић Тешић 2009: 33-45).

Свака квалификација лексике у речнику с аспекта употребне и стилске вредности везана је за време израде речничког текста и важећи језички стандард и природно је да се с временом однос према неким речима може променити. РСЈ је објављен пре осам година, што је релативно кратак период за неке израженије промене. 
лексичка покривеност за разумевање довољно широког круга текстова (исп. Апресян 2016: 14-15).

5.1. Од 135 турцизама, колико их укупно има у посматраном корпусу, 65 се налази у РСЈ. Познато је да је турцизама у Вуково време било много, да су они у највећој мери одраз тадашњих друштвено-историјских дешавања и услова живота и да су с нестанком турског утицаја у највећој мери нестали из језика једнако брзо као што су у њега и ушли (Ивић 1991: 149). Већина њих се данас више не употребљава у свакодневном језику, а многи су познати само зато што су употребљени у народним песмама, па их на тај начин учимо.

5.1.1. Од 65 турцизма који су унети у РСJ, 12 турцизама су историзми - означавају познатије историјске појмове, терминологију која се односи на појаве и појмове из административног и друштвеног живота, дужности, звања и титуле, војску и оружје, одевне предмете, новчане и др. обавезе и сл. који су некада постојали, а данас више не постоје: ага, аршин, бег, беглук, буздован, везир, делија ${ }^{23}$, долама, ${ }^{24}$ и мање познати / фреквентни: алајбег, букагије, делибаша, диздар. Већина ових историзама обележена је у речнику одговарајућим квалификатором ист., док је у случају лексема аршин, бег, букагије и долама тај квалификатор изостао. ${ }^{25}$ Фреквентније турцизме-историзме је целисходно уносити у једнотомник, иако се активно не употребљавају у савременом језику, јер припадају сфери образовања. ${ }^{26}$ Оне друге, мање фреквентне историзме, нема потребе уносити у једнотомни речник (они имају своје место у речницима већег обима, мада поменута граница није јасна и у извесној мери је субјективне природе).

5.1.2. Нема потребе уносити у једнотомник ни оне турцизме који су застарели $^{27}$, или се односе на појмове и предмете некадашњег народног живота па је престала потреба за њиховим именовањем (неке од ових речи се репродукују из дијалеката као стилски маркиране). Такве су речи: aлam ('коњ'), арилама, бехар, бешика, биљур, вајат, дин, ђечерма, ђогат, зубун, иман, које су унете у РCJ без било какве квалификације, па би, према томе, значило да

${ }^{23}$ У песмама и са историјским значењем 'припадник неког рода војске у турској царевини, коњаник' и са значењем 'смео, храбар човек, јунак, јуначина'.

${ }^{24}$ Овој групи турцизама-историзмима припадају и речи: ајдук, анцар, арамбаша, арач, даија, али као нетандардне форме (са изостављеним почетним или унутрашњим х) нису унете y PCJ.

${ }^{25}$ Изостанак квалификатора може бити омашка, резултат разликовања у ауторком приступу обради или пуки превид, на шта је указала М. Радовић-Тешић на примеру РСАНУ, нпр. ага и бег немају квалификатор ист. у овом речнику, као ни турцизам-историзам агалук са значењем „посед”, док га беглук са значењем „посед” има (Радовић Тешић 2009: 38).

${ }^{26}$ Према речима М. Радовић-Тешић (2009: 36), историзми за разлику од архаизама не застаревају, они се уче и памте.

${ }^{27}$ Не мора бити да се увек ради о речи која је некада била раширена у употреби, а данас је застарела. Може бити да реч никада ни није била у широј употреби (исп. Ивић 1991: 149). 
припадају општем лексичком фонду савременог књижевног језика, а није тако. Неки турцизми, који су такође регистровани у РСЈ су у процесу застаревања, па су углавном познати само старијим говорницима српског језика: балчак ${ }^{28}$, диван, дорат, дудук, Ђердан, Ђерђеф, Ђувегија, зулум, зулумћар. О њиховом месту у будућим једнотомним речницима савременог српског језика судиће време. Сличну тенденцију, али у правцу архаизације показују народне речи авлија, баба ('отац'), барјак, барјактар, дућан, које, као и друге турцизмеархаизме са стилском вредношћу, а честе у народним песмама, треба уносити у једнотомни речник: аманет, am, дерт.

5.1.3. За турцизме који су се сасвим одомаћили и усталили и често нема друге лексеме којом би се изразило дато значење или за турцизме којима се именују културне, верске и др. реалије својствене муслиманској средини, није потребно посебно истицати да им је место у једнотомном речнику. ${ }^{29}$ Такве су у посматраном корпусу именице: ала, алка, амајлија, бадем, бећар, боја, бостан, будала, бунар, бурма, гајтан (данас чешће у значењу 'изоловане жице за спровођење електричне струје', него у значењу 'врпца за украшавање одела' које је реализовано у песми), дуд, душманин, зумбул, ибришим, алва, гурабија, амам, була, димије.

5.2. Од осталих именица које су регистроване у РСЈ (а нису турског порекла) издвојићемо оне за које постоје разлози да се изоставе из једнотомника, пошто представљају мање стандардне, регионалне или нераспрострањене форме (у речнику се обично упућују на одговарајуће стандардне варијанте уколико постоје), или зато што застаревају, а у савременом језику имају одговарајуће синониме које говорници активно употребљавају, или су у употреби само у одређеним језичким областима, тј. припадају народним терминологијама. Њихов лексички статус у савременом стандарду није јасно одређен, због чега су вероватно и унете у РСЈ: жарило („в. жарач”), борје, босиље, главња, божјак (,просјак”), градина („врт, башта”), дубрава („шума”), заоблица („печеница”), заход (,залазак (сунца)”), жуборика („бот. в. јасика”).

5.2.1. Код једног броја именица недостају квалификатори којима би се указало на језичку и стилску вредност, одн. на статус нестандардне лексике: алас и госпа $\rightarrow$ арх., грош и дукат $\rightarrow$ ист.

5.2.2. Код неких именица квалификатор је изостао највероватније омашком, нпр. бискуп и игуман немају квалификатор цркв., док га архимандрит и владика имају.

${ }^{28}$ Чувању речи балчак у савременом језику доприноси фразеологизам чији је конституент, B. т. 13.5 .

${ }^{29} \mathrm{O}$ томе је говорио још Вук у Предговору првом издању $\mathrm{CP}$, а започети списак проширују касније Поповић (1983: 51-52) и Пецо (1987: 182). 
5.3. Све глаголске именице из корпуса су регистроване у РСЈ (према правилима која су назначена у Предговору РСJ), осим нестандардног облика Ђевовање.

5.4. Затупљеност именица у РСJ, посматрано према тематским групама, показује који су делови лексичког фонда стабилни, који су мање стабилни, подложнији променама, а који су нестабилни, најподложнији променама и губе се из употребе, рефлектујући у исто време промене које се дешавају у ванјезичкој стварности. Стабилан слој лексике чине лексеме у следећим групама: „глас и гласање” (од 11 речи 10 је регистровано у РС $=90,90 \%$ ), „поседовање и трговина" (од 9 речи 8 је регистровано у РСJ $=88,89 \%$ ), ,земља" (од 23 речи 20 је регистровано у РСJ $=86,96 \%$ ), „тело, делови тела, унутрашњи органи, физиолошке потребе, стања тела, осећања и расположења" (од 44 речи 38 је регистровано у РСJ = 86,36\%), „физичке особине” (од 7 речи 6 је регистровано у РСJ $=85,71 \%$ ), ,небо” (од 16 речи 11 је регистровано у РСJ = 68,75\%), „време” (од 12 речи 9 је регистровано у РС = 75\%), ,животиње” (од 52 речи 42 су регистроване $\mathrm{PCJ}=80,77 \%$ ), „моралне вредности” (од 7 речи 5 је регистровано у РСJ $=71,43 \%$ ), „називи за људе” (од 117 назива 83 је регистровано у РСЈ $=70,94 \%$; у овој групи стабилнији су општи називи и називи за родбинске односе од осталих, док су називи за титуле, иако великим бројем потврђени у РСЈ (74,19\%), углавном историзми) и ,религија и веровања (од 59 речи 42 су регистроване у РCJ = 71,18\%). То су по правилу лексеме домаћег порекла за именовање основних појмова сваке групе које припадају старијем слоју језика, именују (нај)старији слој материјалне културе и зато имају стабилан статус у лексичком систему.

5.4.1. Мање стабилне су групе: „кућа и њени делови” (од 83 речи 55 је регистровано у РСJ = 66,26\%), „биљке” (од 69 речи 44 је регистровано у РСJ = $63,76 \%$ ), „храна” (од 13 назива 8 је регистрована у РСJ =61,53\%), „друштвена организација" (од 36 речи 21 је регистровано у РСJ $=58,33 \%$, у овој групи је знатан број историзама), док у у нестабилан слој лексике спадају групе: „занати и занимања" (од 16 речи 8 је регистровано у РCJ $=50 \%$ ), ,лепота и украсни предмети” (од 17 речи 7 је регистровано у РСJ = 41,18), „одећа” (од 32 речи 9 је регистровано у РCJ = 28,12\%). То су по правилу „новије” лексеме којима се именују предмети и појаве новијег датума везане за развијенији традиционални тип сеоске културе, које укључују елементе страног порекла, највише турског али и друге провенијенције (мађаризми, талијанизми, германизми, галицизми). Лексички статус ових лексема у највећем броју случајева одређен је њиховим страним пореклом и факторима језичке употребе. Регионално су обележене и функционишу као једнозначне јединице у оквиру затворених тематских система којима припадају. С преласком српског језичког стандарда „из вуковске фолклорне фазе у претежно градску фазу" и укључивањем у токове цивилизације 20. века (Ристић 2006: 14) велики број таквих лексема се изгубио баш као 
што се изгубила и материјална култура коју именују, па су наслеђене јединице народне лексике које се нису учврстиле у употреби потиснуте ка периферији лексичког система у пасивни лексички слој (Лазић Коњик 2017: 617). Сведоци смо да је и у садашњем времену лексика којом се именују појаве у области моде (тј. називи за одећу, називи за лепоту и украсне предмете) и занимања (називи за послове), такође највише под страним утицајима, првенствено из енглеског језика, а самим тим и најподложнија променама.

\section{Именице које нису регистроване у РСJ}

6.0. У РСЈ није регистровано 208 именица са посматраног списка.

6.1. Једну групу чине турцизми који су нестали из употребе или су застарели и углавном оправдано нису унети у РСJ, а мањи број турцизми без почетног $x$, са замењеним гласом или фонетске варијанте дијалекатског облика које имају одговарајућу књижевну форму у РСЈ (в. следећу групу): аванииа, авли-марама, агалук, адет, адиђар, азнадар (азнадарче), алет, ал-ћергелет, антерија, ар, арамзада, армаган, астар, ахар, аиамија, ашик, баг, базерђан, балабан, бама, без, безистен, белензуке, белнук, бенђелук, биюиш, бокчалук, бумбул, бунгур, гоние, делкушица, диба и дива, дивит, дизија, дилбер (дилберче), дилчик, долибаша, долија, дувак, ђемија, ђердек, ђидија, ђорда, ђувеглија, Ђузелана, Ђул, Ђулистан, Ђулса, Ђулсија, евлад, ерир, ећим, залф, зерде, зулови, изун. Међу наведеним турцизмима налазе се историзми агалук и баша, архаизам aдет и лексема антерија, за које сматрамо да им је место у РСJ.

6.2. Другу групу чине некњижевне фонетске и др. дијалекатске, покрајинске варијанте чије су књижевне форме потврђене у РСЈ, нпр. аримандрит, артија, арфа, благосов, босиок, братја, бријеме, бумбул, вијерница, вишина, војевода, вщеница, госпоја, госпојииа, гра, греб, греота, гријота, гроот, гувно, дадија, дјевојаство, ђенерал, ђерђев, ђетић, ђечица, зарукавје, зламење, иљада и турцизми: ајдук, ан, анума, аниар, арамбама, арач, аџија, бостан, даија, Ђиздин, имбрик.

6.3. Посебну групу чине деминутиви, хипокористици и ређе аугментативи који имају ограничену употребу или су функционално-стилски маркирани: бабајко, бедрииа, бего, брајен, брале, весаоче, вјетрии, војводић, волак, гребак, дикииа, жбањии, здрављиие, зопия, зорица, иночица, блатушина.

6.4. Специфичну групу чине речи које се активно употребљавају у савременом језику, а значење реализовано у песми није актуелно, тзв. семантички архаизми (11): аљине (мн. 'све (горње и доње) одело што се у исто време носи на телу') банда ('страна'), бања ('јавно купатило'), везир ('везиља'), годиште ('година'), господин и господа ('титула при свечанијем ословљавању особа високог друштвеног положаја, титула оца, браће или рођака кнежевих у 
Црној Гори'), двор ('дом, кућа'), закон ('вера'), застава ('место у дну стола' или 'заседа' (?)), игралиште ('место где се састају виле и играју'). Нека од наведених значења би ипак требало унети у речник савременог језика, јер су веома фреквентна, не само у лирским, већ и у епским песмама (нпр. именица двор у значењу 'дом, кућа' која се појављује 351 пут у СНП 1).

6.5. Два примера су збирне именице које нису распрострањене у савременом језику: зверје и голубље. С друге стране, збирна именица дрвље (од $\partial p в о)$, која такође није унета у РСЈ, члан је фразеологизираног израза дрвље $u$ камење баиати (и сл.) који се активно употребљава у савременом стандардном језику. И неке друге именице из посматраног корпуса су познате у савременом језику, захваљујући томе што су конституенти фреквентних израза: оставити у аманет, као алва, дотерати до балчака, ивер не пада далеко од кладе, живети као бег, обрати бостан.

6.6. Посебну групу чине речи које су нестале из језика, застареле, функционално-стилски обележене, нераспрострањене или из дијалекта, па их савремени говорници не употребљавају и најчешће не знају њихово значење (53): бандијера ('застава'), барета, барна, бељарича, бимбер-грожђе, богословаи, божоле, болта, бор ('бог'), братинство, буниште, ваган, варица, ваћов, велета, вијалиште ('место где вуци завијају'), вијола, виноберје, виојла, властељ, војка, војводић ('војводин син'), војно, враголом, вран ('гавран'), вучи-капа, газимир, гадзамаг, гарофан, гарофиље, гизда, гранатир, дел / дијел ('брдо'), демешкиња, дера ('рупа у огради'), диван-кабанииа, дивор („,нејасно значење (двор)"), дода, дорои, доход, дружба ('дружина'), дундо, ђелсамин, жик, завезиче, заслада, злорад, зличииа ('стомак, желудац'), игриште, илинча (нејасно значење), исполац.

6.7. За именицу вечер, која није унета у РСЈ, мислимо да јој је место у једнотомном речнику савременог српског језика као упућенице на им. вече, која је обичнија реч и више у употреби, док се им. вечер задржала углавном у изразима: добра вечер, Бадња вечер, а има регионални карактер, при чему се њени падежи и даље користе за деклинацију именице вече (о хетероклитичности ове им. в. у Нормативној граматиции т. 164). ${ }^{30}$

Који су разлози нестанка наведених лексема из (активне) језичке употребе?

${ }^{30}$ Динамику језичких промена с аспекта правописне и лексичке норме показује однос према овој лексеми у нашим речницима и правописним приручницима. Тако се у СР, РМС, РСАНУ и речнику уз Правописа из 1960. вече и вечер наводе као равноправне одреднице, под аколадом. У речнику уз Правопис из 1993. и 2010 (2011) наводи се само им. вече. РСЈ у истом речничком чланку наводи две одреднице: вече - вечера (c) и вече - вечери (ж), чиме се каже да облик вечер више није у језичкој употреби. Мишљења смо да се лексема вечер потискује у периферне лексичке слојеве, што се испољава у смањеној учесталости њене употребе али да и даље постоје колебања и разлике између стилских регистара језика и говора, што, поред осталог показује различит начин обраде у различитим речницима. 
7.0. Ако се погледа састав лексема које су нестале из језика или су застареле, показује се да је највећи број њих страног порекла (поред поменутих турцизама ту су још и латинизми: вијола (виојла, вијојла), мађаризми: барна, газдамаг, дороч, грецизми: ваћов и нестандардне варијанте аримандрит, артија, германизми: газимир (нем.-фр.), арфа, талијанизми: банда ('страна'), бандијера, барета, болта, велета, гарофан, ђелсамин, галицизми: газимир (нем.-фр.), турцизми/персијизми: аздија, арамзада (перс.-тур.). Највећи део нове лексике у сваком језику чине управо стране речи (позајмљенице), које улазе у језик да би се њима именовале нове појаве и појмови; али се оне, исто тако, најбрже и губе из језика.

7.1. С друге стране, неке лексеме су одраз историјског времена и друштвених прилика, односно страних утицаја (пре свега турског), а не потреба именовања појмова за које у језику не постоје домаће речи (питање је колико су заиста и биле раширене у употреби) па су се, са нестанком турског утицаја, и оне повукле, а остале су домаће речи (или су се појавиле неке друге стране речи, поново као слика актуелних друштвених прилика): анума, ан, безистен, Ђемија и др.

7.2. Један број речи је нестао заједно са предметима или појмовима који су престали да се употребљавају: амам, бокчалук. Паралелни синонимни називи за исти појам или називи хиперо-хипонимског карактера (родовски појам - врсте), од којих многи данас више нису у употреби, откривају значај и улогу појединих предмета/појмова за свакодневни живот човека онога времена, нпр. називи за коње: am, алат ('коњ риђе боје'), аиамија ('млад коњ'), вранаи ('коњ црне боје'), дорат ('коњ мрке боје'), дора, доро, дорин, ђогат ('коњ беле боје'), Ђогин, ђого, зеленко ('коњ сиве боје'). ${ }^{31}$

7.3. Један број именица су стајаће речи и изрази, како их је Вук назвао, што значи да се никада нису ни употребљавале у свакодневном језику већ само у песмама (од посматраних именица 21 је Вук означио квалификатором cm. (стајаћ)): аздија, алин-камен (у СР алем драги камен), арамлама, бедрица, били-биљур, бисерче, божоле, велен (у СР у изразу: селен велен ${ }^{32}$ ), дева, дивор, дилберче, дојка, драган, драги, дужд, жубер-вода, злато материно (злато 2), игриште, илинча, иноча, иночища). Овај списак би се могао проширити још неким речима за које је Вук махом давао напомене у виду глоса у заградама, ${ }^{33}$ нпр. бабајко, болник, варица, вјетрии, војно, данак, жеђиа, загоркиња, које су у РСАНУ квалификоване као песничке.

\footnotetext{
${ }^{31}$ У песмама такође и лексеме: коњ, коњиц.

${ }^{32}$ Није јасно којој врсти речи припада лексема велен. Ми смо је посматрали као именицу са значњем 'мирисна бљка' (в. РСАНУ, велен'1).

${ }^{33}$ П. Ивић наводи и примере „где је изостала свака напомена у овом смислу ... а ми ипак имамо разлога да верујемо да се реч бар претежно употребљавала само у песмама (нпр. бојак или зеленика)" (Ивић 1991: 77).
} 
7.3.1. Неколико именица међу онима које је Вук означио као стајаће, прошириле су сферу употребе у савременом језику: дојка, драга, драган, драги, дужд.

\section{Лирска језичка слика света}

8.0. Представљена лексика лирских народних песама показује део просечног српског лексикона с краја 18. и почетка 19. века, тј. народну лексику која је у то време била у свакодневној употреби и која, према речима П. Ивића, чини ,језгро речничког блага нашег савременог језика”. Представљајући именице према тематском критеријуму показали смо, такође, стожерни део нарочите лирске фолклорне слике света, у чијем се центру, према добијеним резултатима, налази човек (од крви и меса: бедра, бок, брада, брк, врат, глава, грло, десница, дојка, зној, зуб, бубрег, вид, са унутрашњим физиолошким потребама, стањима и духовним животом: живот, жеђа, здравље, бол, болест, грозница, губавица, воља, весеље, брига, жалост, горопад, жестина, зазор, ијед, дерт, душа), окружен природом (различитим облицима рељефа: брдо, брег, загорје, гора, долина, дубрава, извор; различитим природним појавама и небеским телима: ветар, врућина, гром, дажд, запад, зима, исток, звезда, даница; различитим биљкама и животињама) и повезан са њом.

8.1. Добијена слика такође назначава начин живота човека тога времена: уобичајени начин становања (изглед куће и покућство) и исхране, свакодневне послове, начин облачења, превозна средства, занате и занимања, друштвену организацију, обичаје, обреде, веровања, врсте уметности које су у то време у нашем народу имале главну улогу (музика и плес), доминантне моралне вредности, а тек ће ексцерпција целокупног материјала СНП 1 омогућити да се покаже укупна лирска језичка слика света, која је значајан и нарочит сегмент националне језичке слике света тога времена. ${ }^{34}$

\section{ЗАКЉУЧАК}

9.0. Истраживање показује, с једне стране, да је Вук исцрпно користио српске лирске народне песме као основни корпус за СР, на шта упућује чињеница да је готово све именице са посматраног списка унео у СР. Велики значај српских лирских песама у изради СР огледа се и у томе што је Вук стихове лирских песама више пута наводио као примере за илустрацију значења посматраних именица.

${ }^{34}$ На основу лексичког материјала СР, П. Ивић (1991: 143-155) и М. Поповић (1983) су представили неке елементе начина живота и схватања Вуковог времена; слично је учинио и А. Пецо (1987: 223-235) на основу турцизама у СР. 
9.1. Други део нашег истраживања показао је да је чак $68 \%$ именица са посматраног списка регистровано у речнику савременог српског језика (РСJ). Немали број тих именица припада периферији лексичког система, одн. пасивном лексичком фонду (нестандардна лексика ограничене временске или просторне употребе) или експресивној лексици, а њихова присутност у РС може се објаснити управо великим значајем који народна књижевност и лирске народне песме имају за српски језик и културу. У РСЈ нису ушле оне именице које су страног порекла (најчешће турцизми) а престале су да се користе или су их замениле друге именице (историзми и застареле речи), као ни именице које ни пре два века нису биле широко распрострањене, те именице које су се користиле само у песмама (већина стајаћих речи). Није спорно да због велике културно-историјске вредности и значаја наше народне књижевности један део ове лексике и убудуће треба да има своје место у једнотомним речницима савременог језика, али је зато потребно да критеријуми за њихово уношење буду одређенији, а таква лексика у речницима обележена одговарајућим квалификаторима са становишта актуелног стандарда.

\section{ЛИТЕРАТУРА}

Апресян 2016: Ю. Д. Апресян, Об Активном словаре русского языка, у: Лексикологија и лексикографија у светлу савремених приступа, Зборник научних радова, ур. С. Ристић, И. Лазић-Коњик, Н. Ивановић, Београд: Институт за српски језик САНУ, 13-77.

Ивић 1991: Павле Ивић, О Вуку Караиићу, Целокупна дела ред. М. Радовановић књ. 4, прир. А. Младеновић, Сремски Карловци, Нови Сад: Издавачка књижарница Зорана Стојановића.

Караџић 1814: Вук Караџић, Мала простонародна славено-сербска пјеснаpuйа. Беч: Штампарија Јована Ширера.

Кашић 1986: Јован Кашић, Поговор, у: Сабрана дела Вука Караџића, Српски рјечник (1852), књига једанаеста (2), Београд: Просвета.

Лазић Коњик 2017: Ивана-Лазић Коњик, Лексика традиционалне културе према тематским пољима, у: Словенска терминологија данас, ур. П. Пипер, В. Јовановић, Београд: САНУ, Институт за српски језик САНУ, 613-623.

Латковић 1964: Видо Латковић, Примери из народне епике у другом издању Вукова Рјечника, Анали Филолошког факултета, IV, Вуков зборник I, 243-248.

Младеновић 1964: Живомир Младеновић, Рукописни извори одломака народних песама у Вуковом „Српском рјечнику”, Анали Филолошког факултета, IV, Вуков зборник I, 281-292. 
Пипер/Клајн 2013: Предраг Пипер, Иван Клајн, Нормативна граматика српског језика, Нови Сад: Матица српска.

Пецо 1987: Асим Пецо, Туриизми у Вуковим рјечнициима, Београд: Вук Караџић.

Поповић 1983: Миодраг Поповић, Памтивек. Српски рјечник Вука Ст. Каращића, Београд: Завод за уџбенике и наставна средства.

Радовић Тешић 2009: Милица Радовић-Тешић, С речима и речником, Београд: Учитељски факултет Универзитета у Београду.

Ристић 2006: Стана Ристић, Раслојеност лексике српског језика и лексичка норма, Београд: Институт за српски језик САНУ.

Томић 1938: Божидар Томић, (1938), Вук и Вишњић, у: Књига о Вуку Каpaиићу 1787-1937, Београд: Југословенско професорско друштво, 94-108.

\section{ИЗВОРИ}

Правопис 1960: Правопис српскохрватског књижевног језика, Нови Сад: Матица српска.

Правопис 1993: Правопис српскога језика (1. екавско изд.), Митар Пешикан, Јован Јерковић, Мато Пижурица, Нови Сад: Матица српска.

Правопис 2010 (2011): Правопис српскога језика, Митар Пешикан, Јован Јерковић, Мато Пижурица, Нови Сад: Матица српска.

РСАНУ: Речник српскохрватског књижевног и народног језика, 1-20, Београд: Српска академија наука и уметности, Институт за српски језик, 1959-.

PMC: Речник српскохрватскога књижевног језика, I-VI, Нови Сад: Матица српска, 1967-1976.

PCJ: Речник српског језика. Друго, измењено и поправљено издање. Ур. М. Николић. Нови Сад: Матица српска, 2011.

СНП 1: В. С. Караџић, Српске народне пјесме I, приредио В. Недић, Београд: Просвета, Нолит, 1987.

CP: Караџић, Вук Стефановић, Српски рјечник: дигитално издање. Тома Тасовац (уредник). Београд: Институт за српски језик и Центар за дигиталне хуманистичке науке, 2017. http://raskovnik. org/recnici/VSK.SR 


\title{
THE LEXICON OF SERBIAN FOLK SONGS IN SERBIAN DICTIONARY AND CONTEMPORARY SERBIAN LANGUAGE
}

\begin{abstract}
Summary
This paper examines the lexicon of Serbian lyrical folk songs in the Vuk's Serbian dictionary (Srpski rječnik) and in Matica srpska's single volume Dictionary of the Serbian language (Rečnik srpskoga jezika). The corpus consists of the nouns taken from the first book of Serbian folk songs that begin with letters a, b, v, g, d, d, e, ž, z, i. The work has two parts. The first part is the insight into Vuk's opinion on the lyrical folk songs as material for the Serbian dictionary, a topic not investigated in the previous studies on Vuk's lexicographic work. In the second part, we analyze the distribution of the collected nouns in the contemporary standard language, aiming the analysis towards reconsideration of the nouns' synchronic and diachronic status and justification of their inclusion into Matica's Dictionary of the Serbian language, and presentation of the development of the Serbian language lexicon in the span of two hundred years.

Key words: nouns in Serbian lyrical folk songs, Vuk's Serbian dictionary, Dictionary of the Serbian language.
\end{abstract}

